\begin{tabular}{|l|l|l|l|l|l|}
\hline J. Tek. Ling & Vol. 12 & No. 2 & Hal. 131-142 & Jakarta, Mei 2011 & ISSN 1441-318X \\
\hline
\end{tabular}

\title{
DIVERSITY OF ANTIBACTERIAL COMPOUNDS FROM EUCHEUMA SERRA, HALIMEDA OPUNTIA, AND HYDROCLATHRUS CLATHRATUS
}

\author{
Jana Tjahjana Anggadiredja \\ The Agency for the Assessment and Application of Technology \\ JI. MH Thamrin 8, Jakarta 10340
}

\begin{abstract}
Fourteen compounds were isolated from acetone extracts of three species of seaweeds (Eucheuma serra, a red seaweed, Halimeda opuntia, a green seaweed, and Hydroclathrus clathratus, a brown seaweed) using bioautographic TLC methods and identified using GC-MS. From Eucheuma serra were isolated 8 compounds (3 fatty acids, 3 steroids, and 2 aldehyds). Only two compounds of fatty acid came from Halimeda opuntia, whereas Hydroclathrus clathratus produced 6 compounds (4 fatty acids, one compound each of steroid and ether). All isolated single compounds were tested for their antibacterial activities by the agar diffusion method against the Gram-positive bacteria Staphylococcus aureus, Bacillus subtilis and Streptococcus faecalis, and the Gram-negative bacteria Echerichia coli, Pseudomonas aeruginosa and Salmonella typhimurium. All 14 compounds showed activity against Gram-positive bacteria, especially Bacillus subtilis, and only 2 compounds showed activity against Gram-negative bacteria Escherichia coli. Nine compounds showed activity against Staphylococcus aureus, and 4 compounds showed activity against Streptococcus faecalis. All compounds were not active against Pseudomonas aeruginosa and Salmonella typhimurium bacteria. This study indicated that there is indeed a diversity both in kinds and in molecular structures of the antibacterial substances.
\end{abstract}

Key Words: seaweed, isolated single compound, antibacterial activity

\section{INTRODUCTION}

Marine organisms including seaweed are important sources of biologically active compounds. Therefore, it is important to examine the pharmacological and antimicrobial potentials of metabolite compounds derived from seaweed ${ }^{1,2,3}$. Chemical investigations on seaweeds have proven that these organisms produce a wide variety of structurally unique secondary metabolite compounds. Some of them have been shown to possess biological activity of potential medicinal value ${ }^{1,4,5,6,7,8)}$. From the Laurencia obtusa, Kurosawa and his group isolated two new cyclic polyethers with a squalene skeleton, and one of them is teurilene while the other is thyrsiferyl 23-acetate was remarkably cytotoxic against $\mathrm{P}^{388}$ cells $^{9)}$. Bhakuni \& Silva ${ }^{10)}$ and Aubert et al. ${ }^{11),}$ listed a number of the brominated isolated compounds from Laurencia spp. with quite toxic properties, such as laurencin, laureatin, and laurenterol. From numerous Caribbean and Pacific species of Halimeda were isolated the highly bioactive diterpenoid 
of halimedatrial ${ }^{12,13)}$. Acyclic and monocyclic sesquiterpenes and linear diterpenoids were isolated from Caulerpa spp., also some sesquiterpenes derived from Laurencia spp. of red seaweed was shown a moderate cytotoxic properties ${ }^{14}$.

A total of 18 derivatives of $\mathrm{O}, \mathrm{O}$-dialkylthioand O,O-dialkylthiophosphoric acids were tested for antimicrobial activity using Staphylococcus aureus, Bacillus subtilis, Escherichia coli and Candida albicans; the acivity was found to depend on the length of the alkyl subtituent and/ or the cation size; all derivatives were ineffective against $\mathrm{E}$. coli and C. albicans ${ }^{15)}$. Some fatty acid compounds isolated from several species of red, green, and brown seaweeds were shown to have antibacterial activity $16,17,18,19,20,21,22)$. In a preliminary study, all crude extracts of 21 species of seaweeds collected from Warambadi seashore of Sumba Island were tested against Gram-positive and Gram-negative bacteria. Acetone and methanol extracts of Eucheuma serra and acetone extract of Halimeda opuntia showed activities against Bacillus subtilis, Staphylococcus aureus, Escherichia coli, and Pseudomonas aeruginosa. N-hexane extracts of Halimeda opuntia were positive against Bacillus subtilis, Staphylococcus aureus, and Escherichia coli. Acetone and methanol extracts of Hydroclathrus clathratus also indicated activities against Bacillus subtilis, Staphylococcus aureus, and Escherichia coli ${ }^{23)}$. In a further study, acetone extracts of Eucheuma serra, Halimeda opuntia, and Hydroclathrus clathratus, were fractionated, then isolated by Column Chromatography and Thin Layer Chromatography (TLC) ${ }^{24,25,26,27}$ and the compound isolated were identified by Gas Chromatography-Mass Spectrometry (GCMS) ${ }^{28,29)}$. These compounds belong to fatty acids, steroids, alkaloids, amine, aldehyde, hydrocarbons, and alcohols groups ${ }^{30)}$. Since it is of interest to see the bioactivities of these isolated single compounds, they were tested against Gram-positive and Gram-negative bacteria using the bioautographic TLC assay.

\section{MATERIAL AND METHOD}

\subsection{Material}

\subsubsection{The fraction samples}

The fractions used were ES 1.2, ES 1.2.1, ES 1.2.2, ES 1.6, ES 1.7, ES 1.8, and ES 1.11 from Eucheuma serra, $\mathrm{HO}$ 2.1.2, $\mathrm{HO}$ 2.2, $\mathrm{HO} 2.3 .2$, and $\mathrm{HO} 4.1$ from Halimeda opuntia, and $\mathrm{HC} 1.4, \mathrm{HC} 2.2, \mathrm{HC} 3.1, \mathrm{HC} 3.2$, and $\mathrm{HC} 3.3$ from Hydroclathrus clathratus.

\subsubsection{Bacteria for antibacterial testing}

The bacteria used for antibacterial activities testing were the Gram-positive bacteria Staphylococcus aureus ATCC 25923, Bacillus subtilis ATCC 6633, and Streptococcus faecalis ATCC 29212, whereas the Gram-negative bacteria were Escherichia coliATCC 25922, Pseudomonas aeruginosa ATCC 27853, and Salmonella typhimurium ATCC 14028.

\subsubsection{Chemicals and media}

The solvents and media used were dichloromethane (Merck), acetone (Merck), methanol (Merck), ethanol (Merck), ether (Merck), nutrient agar (OXOID), Mueller Hinton Agar (OXOID), McFarland suspension, paper discs $\varnothing 6 \mathrm{~mm}$ (Schleicher \& Schuell), standard Penicillin-G 10 unit (OXOID), Streptomycin $10 \mu \mathrm{g}$ (OXOID) discs, silica gel plates Si-60 $F_{265}$ (Merck No. 0554), and sephadex LH-20 (Sigma).

\subsubsection{Apparatus}

Vacuum rotary evaporator (Buchii RE-111), laminar airflow, vortex mixer, oven (Memmert-WG), analytical balance (Metler), micro pipettes (Socorex), GC-MS (GC Hewlett Packard, HP 6890 Series, Mass selective detector MSD 5972), GC-MS (Shimadzu QP 5050A type). 


\subsection{Method}

\subsubsection{Preparation of samples}

The TLC was carried out using TLC plate silica gel Si-60 $F_{265}$ (Merck 0554). Standard chromatograms were prepared by applying fractions to a silica gel TLC plate and developing it with ether: methanol (75:25; v/v) under saturated conditions $24,25,26,27)$. According to the procedures of the bioautographic TLC assay, the developed TLC plates were placed directly on the agar surfaces and incubated at $35^{\circ} \mathrm{C}$ for 18 hours. After incubation, plates were taken, the spots which affected the bacterial growth were chosen and the Retention factor (Rf) were measured ${ }^{27,31}$ ). The same fractions which indicated to have effect to the bacterial growth were passed through TLC with the same method. The spots with the same Rf and affected the bacteria were taken off carefully scrapped from the plates and diluted by acetone. Column chromatography was carried out using a Pharmacia column ( $\varnothing 3 \mathrm{~cm} \times 50 \mathrm{~cm}$ ). To purify the compound solution, the column was filled with the adsorbent Sephadex LH20 and then developed with acetone. The fractions were then collected and dried to be used for the antibacterial testing and GC-MS analysis $27,28,29,32,33$.

\subsubsection{Preparation of bacterial suspension}

All bacteria were inoculated on nutrient agar slants and incubated at $35^{\circ} \mathrm{C}$ for 18 hours. Five $\mathrm{ml}$ of sterilized distillated water was added and the bacterial culture was scrapped with an inoculating needle. The bacterial suspension was poured into a sterile test tube and homogenized using a Vortex mixer. The McFarland standard was used for turbidity testing. The bacterial suspension was diluted to obtain a concentration of (5 7) $\times 10^{6}$ cells per $\mathrm{ml}$.

\subsubsection{Evaluation of antibacterial activity by agar diffusion}

All compounds were tested in vitro using paper discs of $6 \mathrm{~mm}$ in $\varnothing$ each containing 50 $\mu \mathrm{g}$ of the extract. The paper discs containing Penicillin-G and Streptomysin $(10 \mu \mathrm{g}$ concentration of each) were used as positive control while the paper discs containing dichloromethane, methanol, and acetone as negative control.

The amount of $0.5 \mathrm{ml}$ of the bacterial suspension was poured onto the MuellerHinton Agar surfaces on Petri dishes, and spread out. The paper discs containing each compound were placed on the agar surfaces and incubated at $35^{\circ} \mathrm{C}$ for 18 hours. After incubation, the diameter of the clear inhibition zones were measured ${ }^{34,35,36)}$.

\section{RESULT}

The results of bioautographic TLC assay showed that there were 16 spots affected the bacterial growth (Figure 1.). The Rf were (0.07), (0.12), (0.2), (0.25), (0.28), (0.32), (0.38), (0.45), (0.50), (0.55), (0.60), (0.67), (0.73), (0.78). Three spots had the same $\operatorname{Rf}(0.50)$. So that there were 14 spots which were processed further.

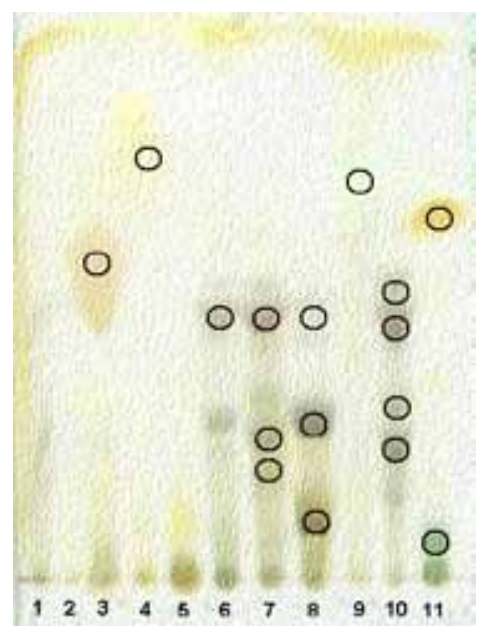

Figure 1. Result of the Bioautographic TLC Assay 
The results of the antibacterial testing and compound identification were shown in Table 1., and the list of active compounds per species shown in Table 2. The 14 identified compounds active against bacteria were:(1) methyl trans-8-octadecenoate or 8-octadecenoic acid, methyl ester (E); (2) 3-hydroxy-nonadeca-5,8,11,14-tetraenoic acid; (3) 3-hydroxy-20-methyl heneicosa5,8,11-trienoic acid; (4) dioctyl phthalate or 1,2- benzene dicarboxylic acid, dioctyl ester; (5) isodecyl octyl phthalate or1,2benzene dicarboxylic acid, isodecyl octyl ester; (6) methyl arachidonate or arachidonic acid methyl ester; (7) methyl eicosa5,8,11,14,17-pentaenoate; (8) androstan-

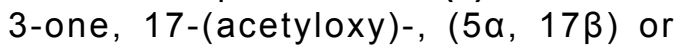
dihydrotestosteron acetic acid; (9) androstan11-one, 3-(acetyloxy)-17-iodo-, (17a) or 3-acetoxy-17 $\alpha$-iodo-androstan-11-one; (10) pregn-15-en-20-one, 17-methyl-, (5a-17.xi.); (11) cholest-5-en-3ß-ol, 24-propylidene; (12) 9-[3-(1-hydroxy-butyl)-oxiranyl]-nonanal; (13) 11-[3-(1-hydroxy-butyl)-oxiranyl]-undecanal; (14) 3,7,11-trimethyl-1-(3-methyl-butoxy)dodec-2-en (Figure 2. up to 15.).<smiles>CCCCCCCCC/C=C/CCCCCC(=O)OC</smiles>

Figure 2. Compound (1), Methyl trans-8octadecenoate or 8-Octadecenoic acid, methyl ester, (E)

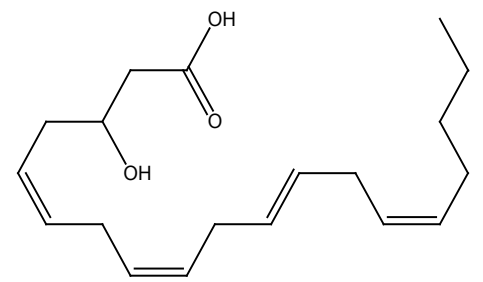

Figure 3. Compound (2), 3-hydroxynonadeca-5,8,11,14-tetraenoic acid

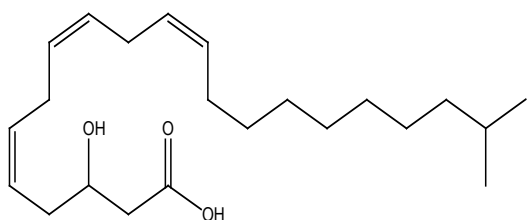

Figure 4. Compound (3), 3-hydroxy-20methyl heneicosa-5,8,11-trienoic Acid

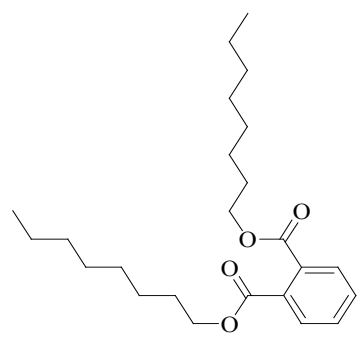

Figure 5. Compound (4), Dioctyl phthalate or 1,2- Benzenedicarboxylic acid, dioctyl ester

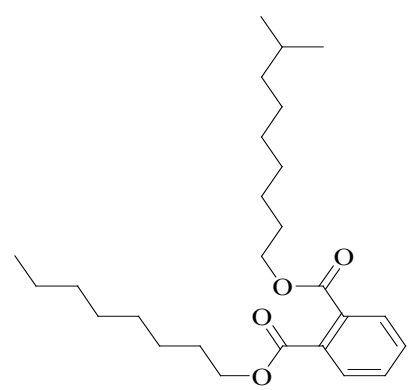

Figure 6. Compound (5), Isodecyl octyl phthalate or 1,2Benzenedicarboxylic acid, isodecyl octyl ester

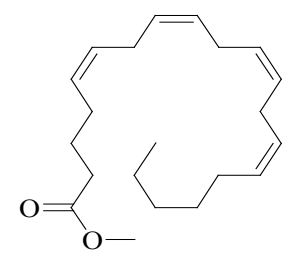

Figure 7. Compound (6), Methyl arachidonate or Arachidonic acid methyl ester 


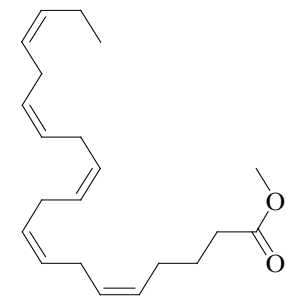

Figure 8. Compound (7), Methyl eicosa5,8,11,14,17-pentaenoate

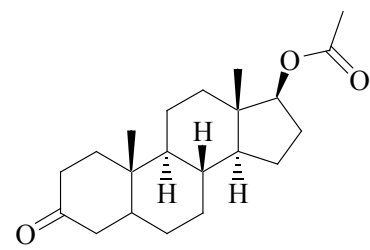

Figure 9. Compound (8), Androstan-3-one, 17-(acetyloxy)-, $(5 \alpha, 17 \beta)$ or Dihydrotestosteron acetic acid<smiles>CC(=O)OC1CCC2(C)C(CCC3C4CCC(I)C4(C)CC(=O)C32)C1</smiles>

Figure 10. Compound (9), Androstan-11-one, 3-(acetyloxy)-17-iodo-, (17 $\square$ ) or 3-Acetoxy-17a-iodo-androstan11-one

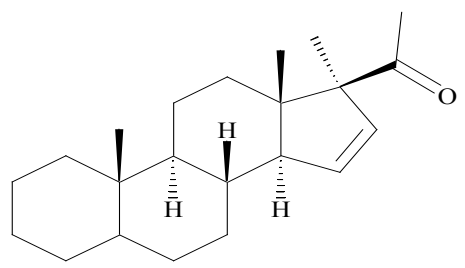

Figure 11. Compound (10), Pregn-15-en-20one, 17-methyl

Figure 12. Compound (11), Cholest-5-en-3ßol, 24-propylidene

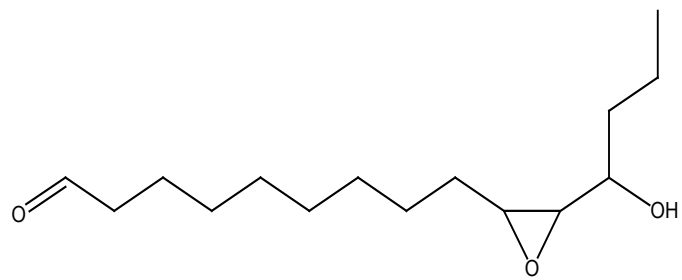

Figure 13. Compound (12), 9-[3-(1-hydroxybutyl)-oxiranyl]-nonanal<smiles>C=CCCCCCCCCCC1CC1[C@H](O)CCC</smiles>

Figure 14. Compound (13), 11-[3-(1-hydroxybutyl)-oxiranyl]-undecanal<smiles>CC(=CCOCCC(C)C)CCCC(C)CCCC(C)C</smiles>

Figure 15. Compund (14), 3,7,11-trimethyl1-(3-methyl-butoxy)-dodec-2-en

The compounds (1) up to (7) are of the fatty acid group, compounds (8) up to (11) are of the steroid group, compounds (12) and (13) are of the aldehyde group, and compound (14) of the ether group. All of the 14 compounds showed activity against Gram-positive bacteria, especially Bacillus subtilis ( $100 \%$ of the identified compounds). Only 2 out of 14 compounds (14,3\%) were active against Gram-negative bacteria of Escherichia coli. All compounds were not active against $P$ seudomonas aeruginosa and Salmonella typhimurium. Nine out of the 14 compounds $(64.3 \%)$ were active against Staphylococcus aureus, and 4 out of the 14 compounds $(28.6 \%)$ were active against Streptococcus faecalis.

The 8 identified compounds from Eucheuma serra which were active against 
bacteria are 3 fatty acids, 3 steroids, and 2 aldehydes. Only two compounds, all fatty acids, from Halimeda opuntia were active against bacteria. Six compunds from Hydroclathrus clathratus which were active against bacteria are 4 fatty acids, one compound a steroid and another one an ether.

\section{DISCUSSION}

The performance of antibacterial activities as indicated by inhibition zone in this study was substantially lower than the data reported in a previous study which used whole extracts. These seem to indicate that a synergism effect occurred between compounds in the whole extract sample compared to the single compound.

Most of the identified compounds showed an inhibition activity against both Gram-positive as well as Gram-negative bacteria. Almost all identified compounds had a greater effect against the Gram-positive bacteria Bacillus subtilis and Staphylococcus aureus (Table 1.). It is important to distinguish between the agents which are active against Gram-positive bacteria only and those which are also active against Gram-negative bacteria. Generally, many compounds have antibacterial capability against Gram-positive bacteria, but lesser number was capable of attacking Gram-negative bacteria ${ }^{37}$. The Gram-negative bacteria have outer membrane which protected bacteria cells from toxic agents ${ }^{34,38)}$. The outer membrane and the quite narrow of porin channels in the membrane have added protection to the Gram-negative bacteria. For this reason, the diffusion of water-soluble antibacterial agents larger than 700 Daltons through the outer membrane of Gram-negative bacteria is severely limited ${ }^{34,37,38,39)}$. Furthermore, the lipid bi-layer region of the Gram-negative bacteria's outer membrane usually has a low permeability toward lipophilic molecules. Consequently, the larger and more lipophilic antibiotics tend to have significant activity against Gram-positive bacteria only ${ }^{37,40)}$.

There were seven identified compounds of fatty acid group and four compounds of steroid group were active against bacteria, as well as two other compounds of the aldehyde group and one compound of ether also showed active against bacteria (Table 1.). The fatty acids, e.g. oleic acid and arachidonic acid (eicosatetra-5,8,11,14enoic acid) are also found in cell membranes, but in addition they act as precursors of biologically active metabolites, for example, oleic acid is the biosynthetic precursor of polyacetylenes like ceprenynic acid 41). Arachidonic acid is the biosynthetic precursor of a large family of metabolites known as eicosanoids, which include the pharmacologically important prostaglandins and leukotrienes ${ }^{41}$. The biosynthesis of fatty acids is under the control of enzyme called fatty acid synthases, and the main building block of fatty acid biosynthesis is acetate in the form of acetyl-SCoenzyme-A or acetylSCoA ${ }^{42)}$. Acetyl-Scoenzyme $A$ is also the main building block of the terpenoids and steroids. All organisms contain a discrete cell nucleus (eukaryotes) synthesize steroids, or have the capacity to affect a cyclization of squalene to form steroid-like molecules, or have an absolute requirement for them in their diet. Other steroids are metabolized to produce biologically active molecules like the human hormones and vitamins D ${ }^{41,43)}$. Some marine invertebrates share fatty acid profiles which are unique in their process of biosynthesizing high amount of polyunsaturated fatty acids with a variety number and position of unsaturated group. Some of marine fatty acids, such as $(5 Z, 9 Z)$ 14-methyl-5,9-pentadecadienoic acid, are antibacterial against Gram-positive bacteria Streptococcus and Staphylococcus ${ }^{44)}$.

More active compounds were found in Eucheuma serra if compared to Halimeda opuntia and Hydroclathrus clathratus. Two interesting active compounds found in this study are worth noting. There are methyl trans-8-octadecenoate or 8-Octadecenoic 
acid, methyl ester (E) (1), a fatty acid in trans formation from Hydroclathrus clathratus, and androstan-11-one, 3-(acetyloxy)-17-iodo-,

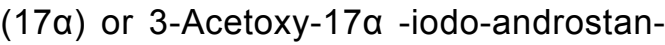
11-one (9), a steroid containing iodium from Eucheuma serra. Both compounds were active against Gram-positive (Staphylococcus aureus, Bacillus subtilis, and Streptococcus faecalis) and Gram-negative bacteria (Escherichia coli), especially the compound (9) was active against all the Gram-positive bacteria (Table 1.).

Robles et al., ${ }^{45)}$ suggested that antibiosis in algae is extremely complex and involves numerous different activities which manifest themselves differently with respect to habitat, season and life history stages. It means that the difference in quantities and qualities of seaweed's active secondary metabolite products were synthesized under different conditions, such as seasons, geographic location, habitat factors and genetics which affect the spectrum of biologically active secondary metabolites produced. The different results indicated the possibility that genera, species, and their physiological state or life stages, affected the capability of the seaweed to synthesize different quantities and qualities of bioactive secondary metabolites.

The active compounds were presented in Table 2., displayed fatty acid, steroid, aldehyde, and ether groups, respectively. The antibacterial compounds of fatty acids are unsaturated groups. Based on the molecular structures of active compound, it could be suggested that the number and position of unsaturated in fatty acids are the key of its antibacterial activity. As in 3-hydroxy-20methyl heneicosa-5,8,11-trienoic acid (Figure 4.) which has three double bond showed more active than its analog of 3-hydroxy-20 methyl heneicosa-5,8-dienoic acid. Moreover, the number of unsaturated was also supposed as the factor of the activity of methyl eicosa5,8,11,4,17-pentaenoate (Figure 8.). Active compound was also showed by phtalate derivates such as dioctyl phtalate (Figure
5.) and isodecyl octyl phtalate (Figure 6.). But the other phtalate derivates, namely, 1,2-benzendicar-boxylic acid, bis (2-ethylexyl) ester was not active, because of the presence of 2 ethyl substituents which caused steric hindrance at carbonyl ester groups.

The active compounds of aldehyde group were also obtained. The activity factor of this group may be caused by the presence of epoxy group as in 9-[3-(1-hydroxy-butyl)oxiranyl]-nonanal and 11-[3-(1-hydroxybutyl)-oxiranyl]-undecanal respectively (Figure 13. \& 14.). The other active compounds were steroid and ether groups. The activity of steroids could be caused by ketone group in the steroid ring and side chain of acetyloxy group, as well as the presence of halogen (iodine) substituent. Moreover, the ether compound was also active as showed by 3,7,11-trimethyl-1-(3methyl-butoxy)-dodec-2-en (Figure 15.).

\section{CONCLUSION}

The results of this study indicated that three seaweed species (Eucheuma serra, Halimeda opuntia, and Hydroclathrus clathratus) which were collected from Warambadi seashore of Sumba Island, showed a significant capacity to produce a variety of compounds with antibacterial activities.

The 14 compounds with an active antibacterial activity, consisted of 8 compounds from Eucheuma serra (3 fatty acids, 3 steroids, 2 aldehyds), two fatty acids compounds from Halimeda opuntia, and six compounds from Hydroclathrus clathratus (4 fatty acids, and one compound each of the steroid and ether group). All compounds were active against Gram-positive bacteria especially Bacillus subtilis and only 2 compounds showed active against the Gramnegative Escherichia coli. All compounds were not active against Pseudomonas aeruginosa and Salmonella typhimurium.

In term of antibacterial activity, two interested active compounds are methyl trans-8-octadecenoate or 8-octadecenoic 
acid, methyl ester (E) (a fatty acid in trans formation from Hydroclathrus clathratus), and androstan-11-one, 3-(acetyloxy)-17-iodo-,

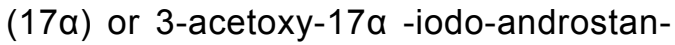
11-one (a steroid contain iodium from Eucheuma serra), both of compounds were active against Gram-positive and Gramnegative bacteria.

The molecular structures produced showed that the fatty acids active compounds are of the unsaturated group. It is likely that the number and position of unsaturated in fatty acids are important factors of its antibacterial activity. Two of four compounds of aldehydes were active substances, and in this case may be caused by the presence of epoxy group in the molecular structures, whereas, the active compounds of steroids could be caused by the presence of ketone group in the steroid ring and acetyloxy group in the side of chain, as well as the presence of iodine substituent.

\section{REFERENCES}

1. Baker, J.T. 1984. Seaweed in pharmaceutical studies and application. Hydrobiologia, 116/117: 2940.

2. Faulkner, D.J. 1998. Marine natural products. Natural Products Reports 15: 113-158 (and his preceding reports).

3. Gonzales, A., G. Platas, A. Basilio, A. Cabello, J. Gorrochategui, I. Suay, F. Vicente \& F. Pelaez. 2001. Screening of antimicrobial activities in red, green and brown macro algae from Gran Canaria (Canary Island, Spain) Int. Microbiol, 4: 35-40.

4. Fenical, W. \& J.P. Valerie. 1984. Antibacterial and cytotoxic terpenoids from tropical green algae of the family Undoteaceae. In: Proc. 11th Int. Seaweed Symp. Hydrobiologia, 116/117: 135140.

5. Jing-wen Ma \& Wei-ci Tan. 1984. Screening for antimicrobial activities in marine algae from the Qingdao coast China. Hydrobiologia, 116/117: 517-520.
6. Moore, R.E. 1978. Algal nonisoprenoids. In: Scheuer P.J. (eds.). 1978. Marine natural Products, Chemical and Biological Perspective. Academic Press. New York. 1:44-171.

7. Konig, G.M., A.D. Wright, O. Sticher, C.K. Anghofer \& J.M. Pezutto. 1994. Biological activities of selected marine natural products. Planta Medica 60: 532-537.

8. Munro, M.H.G., J.W. Blunt, E.J. Dumdei, S.J.H. Hickford, R.E. Lill, S. Li, C.N. Battersgill \& A.R. Duckworth. 1999. The discovery and development of marine compounds with pharmaceutical potential. J. of Biotechnology. 70: 1525.

9. Kitagawa, I. 1988. Studies in marine pharmaceutical chemistry research in Japanese Universities. In: Jefford C.W., K.L. Rinehart \& L.S. Shield (eds.). 1988. Pharmaceuticals and the sea. Technomic Publishing Co. Inc. 55-71.

10. Bhakuni, D.S. \& M. Silva. 1974. Biodynamic substances from marine flora. Botanica Marina. 17(1): 40-51.

11. Aubert, M., J. Aubert, \& M. Gauthier. 1979. Antibiotics substances from marine flora. In: Hoppe H.A., T. Levring \& Y. Tanaka. (eds.). 1979. Marine Algae in Pharmaceutical Science. Walter de Gruyter. Berlin. 267-291.

12. Valerie, J.P. \& W. Fenical. 1983. Isolation of halimedatrial: chemical defense adaptation in the calcareous reef-building alga halimeda. Science. 221: 747-749.

13. Ballantine, D.L., W.H. Gerwick, S.M. Velez, E. Alexander \& P. Guevara. 1987. Antibiotic activity of lipid-soluble extracts from Caribbean marine algae. Hydrobiologia, 151/152: 463-469.

14. Konig, G.M. \& A.D. Wright. 1993. Algal secondary metabolites and their pharmaceutical potential. In: Human Medicinal Agent From Plants. Chp. 19. 276-293. 
15. Devinsky, F., F. Gregan, F. Bitterrova \& V. Cupkova. 1982. Antimicrobial activity of some salts of dialkylthiophosphoric acids. Folio Microbiol. 27(3): 178-81.

16. Gerwick, W.H., W. Fenical \& J.N. Norris. 1985. Chemical variation in the tropical seaweed Stypopodium zonale (Dictyotaceae). Phytochemistry 24:1279-1283.

17. Gerwick, W.H. 1994. Structure and bisynthesis of marine algal oxylipins. Biochim Biophys Acta. 1211(3):243-55.

18. Faulkner, D.J. 1993. Marine natural products chemistry: Introduction. Chem. Rev. 93: 1671-1672.

19. Faulkner, D.J. 2000. Highlights of marine natural products chemistry (1972-1999). Nat. Prod. Rep. 17: 1-6.

20. Sheu, J.H., S.Y. Huang \& C.Y. Duh. 1996. Cytotoxic oxygenated desmosterols of the red alga Galaxaura marginata. J. Nat. Prod. 59: 23 - 26.

21. Carter, G.T. 2002. Marine natural products as a resources for drug discovery: opportunities an challenges. In: N. Target (ed.). 2002. Marine Biotechnology in the Twenty-First Century: Problem, Promise and Products. National academy press. Washington, DC: $x i+117 p$.

22. Fenical, W. 2001. Marine Pharmaceuticals. Oceans and human health roundtable report, National Institute of Environmental Health Sciences and National Science Foundation, North Carolina: $27 \mathrm{pp}$.

23. Anggadiredja, J.T. 2004a. Screening of antibacterial activities in selected Indonesian Red, Green, and Brown seaweeds. In: Anggadiredja, J.T. 2004. Diversity of Antibacterial Substances from Selected Indonesian Seaweeds. Doctoral Dissertation. University of Indonesia. pp. 14-44.

24. Stahl, E. (eds.). 1965. Thin Layer Chromatography; a Laboratory Handbook. Academic Press Inc. Publishers. London. $x v+539 p$.

25. Touchstone, J.C. \& V. Kogers.
1980. Thin Layer Chromatography: Quantitative Environmental and Clinical Applications. John Wiley and Sons Inc. $1-17$.

26. Sherma, J. 1996. Handbook of Thin Layer Chromatography. 2nd ${ }^{\mathrm{Ed}}$. Revised and expanded chromatographic science series. Mercel Dekker Inc. USA. Vol. 76: $3-36$.

27. Supriyono, A. 1997. Biologisch aktive Naturstoffe aus tropischen Schämmen Südostasiens. Dissertation Doctorgrades der Bayerischen JuliusMaximilians-Universität Würzburg. ix + $169 p$.

28. Silverstein, R.M. \& F.X. Webster. 1998. Spectrometric Identification of Organic Compounds. Sixth Edition. John Wiley \& Sons Inc. xiv +482 .

29. Cong, P. \& K. Su. 2000. Hand Book of Analytical Chemistry: Mass Spectrum Analysis. $2^{\text {nd }}$ Ed. Vol. 9. Chemical Industry Press. Beijing.

30. Anggadiredja, J.T. 2004b. Diversity of compounds from extracts of Eucheuma serra, Halimeda opuntia, and Hydroclathrus clathratus. In: Anggadiredja, J.T. 2004. Diversity of Antibacterial Substances from Selected Indonesian Seaweeds. Doctoral Dissertation. University of Indonesia. pp. 45-175.

31. Hamburger, M.O. \& G.A. Cordell. 1987. A direct bioautographic TLC assay for compounds possessing antibacterial activity. J. Nat. Prod. 50: 19-22.

32. Wiley 275.L Database. Enchance chem station. G170BA version B.01.00. Copyright $@$ Hewlett Packard1989-1998.

33. NIST 107.LIB database. NIST Chemistry WebBook. Copyright (C) US Secretary of Commerce. 2001, 2003.

34. Prescott, L.M., J.P. Harley \& D.A. Klein. 1993. Microbiology. 2nd edition. Wm.C. Brown Publishers, Dubuque. Xxx + 912p.

35. Mitchell, J.K. \& W.E. Carter. 2000. Modeling antimicrobial activity of 
cloroxTM using an agar-diffusion test: a new twist on an old experiment. Bioscene. 26(3): 9-13.

36. Osterhage, C. 2001. Isolation, structure determination and biological activity assessment of secondary metabolites from marine-derived fungi. Dissertation Doctorgrades, Facultät der Technischen Universität Carolo-Wilhelmina zu Braunschweig: $x i+186 p$.

37. Glazer, A.N. \& H. Nikaido. 1998. Microbial Biotechnology: Fundamentals of Applied Microbiology. W.H. Freeman Company. New York. Xviii + 662p.

38. Singh, M.P., P.J. Peterson, W.J. Weiss, F. Kong \& M. Greenstein. 2000. Saccharomicins, novel heptadecagycoside antibiotics produced by Saccharothrix espanaensis: antibacterial and mechanistic acitivities. Antimicrobs. Agents, Chemother. 44(8) 2154-2159.

39. Fajardo, D.A., J. Cheung, C. Ito, E. Sugawara, H. Nikaido \& R. Mirsa. 1998. Biochemistry and regulation of a novel Eschericia coli $\mathrm{K}_{12}$ protein, OpmG, which produces unusually large channels. J. Bacteriol 180(9): 44524459.

40. Cosson, P., L. Zulianello, O.J. Lambert, F. Faurisson, L. Gebbie. M. Benghezal, van Delden, L. Kosjancic \& T. Kohler. 2002. Pseudomonas aeruginosa virulence analyzed in a Dyctyostelium discoideum host system. J. Bacteriol. 184(11): 3027-3033.
41. Mann, J. 1994. Chemical Aspect of Biosynthesis. Oxford University Press. $\mathrm{v}+92$.

42. Rawlings, B.J. 1997. Biosynthesis of polyketides. In: Natural Product Reports. 14.523.

43. Harrison, D.M/ 1990. Biosynthesis of triterpenoids, steroids, and carotenoids. In: Natural Product Report. 7.549

44. Carballeira, N.M., S. Sostre \& D.L. Ballantine. 1999. The fatty acid composition of tropical marine algae of the genus Halimeda (Chlorophyta). Bot. Mar. 42: 383-387.

45. Robles, C.P.O., D.L. Ballantine, \& W.H. Gerwick. 1996. Dynamics of antibacterial activity in three species of Caribbean marine algae as a function of habitat and life history. Hydrobiologia, 326/327: 457-462.

46. Scheuer, P.J. 1990. Some marine ecological phenomena: chemical basis and biomedical potential. Sciece. 248: 173-177.

47. Anggadiredja, J.T., Hasanudin, A.S. Sidiq, A. Pratomo \& Rudyansyah. 1996. Screening of marine algae from Warambadi seashore of Sumba Island of Indonesia for antibacterial activity. Phytomedicine, Vol 3 Suppl. I: 37. 
Table 1. Antibacterial activity of identified compounds

\begin{tabular}{|c|c|c|c|c|c|c|c|}
\hline No & Compound & S.aureus & B.subtilis & S.faecalis & E.coli & P.aeruginosa & S.typhimurium \\
\hline \multicolumn{8}{|c|}{ Fatty Acids } \\
\hline 1 & $\begin{array}{l}\text { Methyl trans-8- } \\
\text { octadecenoate or } \\
\text { 8-Octadecenoic acid, } \\
\text { methyl ester, (E) }\end{array}$ & 6.8 & 7.4 & - & 6.5 & - & - \\
\hline 2 & $\begin{array}{l}\text { 3-Hydroxy-nonadeca- } \\
5,8,11,14 \text {-tetraenoic } \\
\text { acid }\end{array}$ & 6.5 & 7.0 & - & - & - & - \\
\hline 3 & $\begin{array}{l}\text { 3-Hydroxy-20-methyl } \\
\text { heneicosa-5,8,11- } \\
\text { trienoic acid }\end{array}$ & 6.8 & 6.8 & - & - & - & \\
\hline 4 & $\begin{array}{l}\text { Dioctyl phthalate or 1,2- } \\
\text { Benzenedicarboxylic } \\
\text { acid, dioctyl ester }\end{array}$ & 6.7 & 7.4 & - & - & - & - \\
\hline 5 & $\begin{array}{l}\text { Isodecyl octyl phthalate } \\
\text { or } 1,2-\text { Benzene dicar- } \\
\text { boxylic acid, isodecyl } \\
\text { octyl ester }\end{array}$ & 7.0 & 7.5 & 6.5 & - & - & - \\
\hline 6 & $\begin{array}{l}\text { Methyl arachidonate or } \\
\text { Arachidonic acid methyl } \\
\text { ester }\end{array}$ & 6.5 & 6.8 & - & - & - & - \\
\hline 7 & $\begin{array}{l}\text { Methyl eicosa- } \\
5,8,11,14,17- \\
\text { pentaenoate }\end{array}$ & - & 6.5 & - & - & - & - \\
\hline \multicolumn{8}{|c|}{ Steroids } \\
\hline 8 & 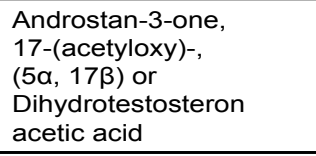 & - & 6.6 & - & - & - & - \\
\hline 9 & $\begin{array}{l}\text { Androstan-11-one, } \\
\text { 3-(acetyloxy)-17-iodo-, } \\
\text { (17a) or 3-Acetoxy-17a } \\
\text {-iodo-androstan-11-one }\end{array}$ & 7.0 & 7.8 & 7.0 & 6,5 & - & - \\
\hline 10 & $\begin{array}{l}\text { Pregn-15-en-20-one, } \\
\text { 17-methyl } \\
\end{array}$ & - & 6.8 & 6.5 & - & - & - \\
\hline 11 & $\begin{array}{l}\text { Cholest-5-en-3 } \beta \text {-ol, } \\
\text { 24-propylidene }\end{array}$ & 7.0 & 7.0 & - & - & - & - \\
\hline \multicolumn{8}{|c|}{ Aldehydes } \\
\hline 12 & $\begin{array}{l}\text { 9-[3-(1-hydroxy-butyl)- } \\
\text { oxiranyl]-nonanal }\end{array}$ & - & 6.7 & - & - & - & - \\
\hline 13 & $\begin{array}{l}\text { 11-[3-(1-hydroxy-butyl)- } \\
\text { oxiranyl]-undecanal }\end{array}$ & - & 6.7 & - & - & - & - \\
\hline \multicolumn{8}{|c|}{ Ether } \\
\hline 14 & $\begin{array}{l}\text { 3,7,11-Trimethyl-1-(3- } \\
\text { methyl-butoxy)-dodec- } \\
\text { 2-en }\end{array}$ & 6.7 & 7.0 & 6.5 & - & - & - \\
\hline \multicolumn{2}{|c|}{$\begin{array}{l}\mathrm{P}-10=\text { Penisllin-G (Conc. } 10 \\
\mu \mathrm{g})\end{array}$} & 8.8 & 8.3 & 8.0 & 7.8 & - & 8.0 \\
\hline \multicolumn{2}{|c|}{$\begin{array}{l}\mathrm{S}-10=\text { Streptomycin (Conc. } \\
10 \mu \mathrm{g})\end{array}$} & 18.5 & 20.5 & 18.0 & 2.0 & 10.5 & 11.0 \\
\hline \multicolumn{2}{|c|}{$\mathrm{C}($ Acetone $)=$ control } & - & - & - & - & - & - \\
\hline
\end{tabular}

Gram-positive bacteria : Staphylococcus aureus ATCC 25923; Bacillus subtilis ATCC 6633; Streptococcus faecalis ATCC 29212; Gram-negative bacteria : Escherichia coli ATCC 25922; Pseudomonas aeruginosa ATCC 27853; Salmonella typhimurium ATCC 14028 
Table 2. List of the active compounds of Eucheuma serra, Halimeda opuntia, and Hydroclathrus clathratus

\begin{tabular}{|c|c|}
\hline No. & Compound \\
\hline \multicolumn{2}{|c|}{ Eucheuma serra } \\
\hline & Fatty Acids \\
\hline 1 & 3-Hydroxy-nonadeca-5,8,11,14-tetraenoic acid \\
\hline 2 & 3-Hydroxy-20-methyl heneicosa-5,8,11-trienoic acid \\
\hline \multirow[t]{2}{*}{3} & Dioctyl phthalate or 1,2- Benzenedicarboxylic acid, dioctyl ester \\
\hline & Steroids \\
\hline 4 & 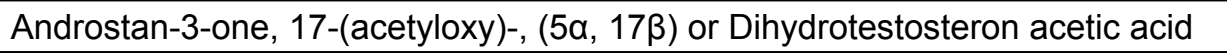 \\
\hline 5 & 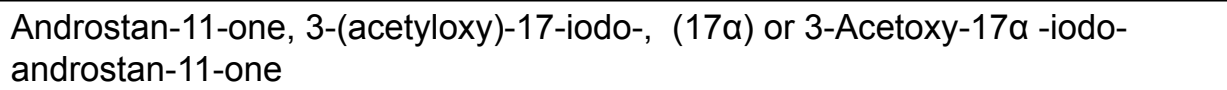 \\
\hline \multirow[t]{2}{*}{6} & Pregn-15-en-20-one, 17-methyl \\
\hline & Aldehydes \\
\hline 7 & 9-[3-(1-hydroxy-butyl)-oxiranyl]-nonanal \\
\hline 8 & 11-[3-(1-hydroxy-butyl)-oxiranyl]-undecanal \\
\hline \multicolumn{2}{|c|}{ Halimeda opuntia } \\
\hline & Fatty acids \\
\hline 1 & Dioctyl phthalate or 1,2- Benzenedicarboxylic acid, dioctyl ester \\
\hline 2 & Isodecyl octyl phthalate or 1,2- Benzene dicar- boxylic acid, isodecyl octyl ester \\
\hline \multicolumn{2}{|c|}{ Hydroclathrus clathratus } \\
\hline & Fatty acids \\
\hline 1 & Methyl trans-8-octadecenoate or 8-Octadecenoic acid, methyl ester, (E) \\
\hline 2 & Methyl arachidonate or Arachidonic acid methyl ester \\
\hline 3 & Methyl eicosa-5,8,11,14,17-pentaenoate \\
\hline \multirow[t]{2}{*}{4} & Dioctyl phthalate or 1,2- Benzenedicarboxylic acid, dioctyl ester \\
\hline & Steroids \\
\hline \multirow[t]{2}{*}{5} & Cholest-5-en-3ß-ol, 24-propylidene \\
\hline & Ether \\
\hline 6 & 3,7,11-Trimethyl-1-(3-methyl-butoxy)-dodec-2-en \\
\hline
\end{tabular}

